\title{
Use of metaphylactic protocols based on the risk to develop bovine respiratory diseases in feedlot cattle
}

\author{
Layane Queiroz Magalhães $^{1 *}$ Anderson Lopes Baptista ${ }^{1}$ Pedro de Almeida Fonseca ${ }^{1}$ \\ Guilherme Lobato Menezes ${ }^{1}$ Geison Morel Nogueira ${ }^{1}$ Selwyn Arlington Headley ${ }^{2,3}$ \\ Juliana Torres Tomazi Fritzen ${ }^{4}$ Amauri Alcindo Alfieri ${ }^{4}$ João Paulo Elsen Saut ${ }^{1}$
}

${ }^{1}$ Laboratório de Saúde em Grandes Animais, Universidade Federal de Uberlândia (UFU), Avenida Mato Grosso, 3289, Bloco 2S, Umuarama, 38405-314, Uberlândia, MG, Brasil. E-mail: layanequeirozmagalhaes@gmail.com. "Corresponding author.

${ }^{2}$ Multi-user Animal Health Laboratory, Unidade de Biologia Molecular, Universidade Estadual de Londrina (UEL), Londrina, PR, Brasil.

${ }^{3}$ Laboratório de Patologia Animal, Universidade Estadual de Londrina (UEL), Londrina, PR, Brasil.

${ }^{4}$ Laboratório de Virologia Animal, Universidade Estadual de Londrina (UEL), Londrina, PR, Brasil.

\begin{abstract}
Bovine respiratory diseases (BRD) affect production rates negatively because it compromise health and well-being of the affected animal. The hypothesis of this study was that the use of metaphylactic protocols based on the risk to develop BRD would reduce morbidity and pulmonary lesions. For this purpose, the aims of this study were to evaluate the effect of two metaphylactic protocols on the morbidity of feedlot cattle with a known sanitary history, occurrence of pulmonary lesions at slaughter, and the possible participation of Mannheimia haemolytica, Histophilus somni, Bovine alphaherpesvirus 1 (BoHV-1) and bovine respiratory syncytial virus (BRSV) in the development of BRD. An experimental study was designed in which 3,094 adult, male, cattle, were grouped according to the risk to develop BRD: a) group without metaphylaxis $(n=2,104)$, low-risk animals; b) metaphylaxis group with oxytetracycline ( $n=789)$, moderate-risk animals; c) metaphylaxis group with tildipirosin $(n=201)$, high-risk animals. All cattle were immunized against pathogens associated with BRD (BoHV-1, BVDV, BRSV, PI3). The morbidity for BRD was 8.2\% (253/3,094); cattle within the moderate-risk group for BRD had the lowest frequency (6.1\%), followed by high-risk animals with tildipirosin metaphylaxis (6.5\%) and low-risk without metaphylaxis (9.1\%) (P=0.019). At the abattoir, $1.2 \%$ of lungs with lesions were found. There was a difference $(P=0.036)$ in the frequency of pulmonary lesions between healthy animals (1.1\%) and those diagnosed with BRD (2.8\%). Two agents associated with BRD were identified by PCR assays in the lungs ( $n=37)$ of cattle: M. haemolytica (16.2\%) and H. somni (5.4\%). In addition, concomitant infections involving these pathogens were identified in the lungs of two steers. These results demonstrate that the use of metaphylactic protocols, based on the risk to develop BRD, reduces morbidity and pulmonary lesions in affected cattle. Furthermore, pulmonary lesions were more frequent in animals with a history of BRD.
\end{abstract}

Key words: Histophilus somni, Mannheimia haemolytica, pulmonary lesions.

Efeito do uso de protocolos metafiláticos segundo o risco de doença respiratória bovina em confinamentos

RESUMO: As doenças respiratórias dos bovinos (DRB) afetam negativamente as taxas de produção por comprometer a saúde e o bem-estar animal. A hipótese deste estudo foi que o uso de protocolos metafiláticos com base no risco de desenvolvimento de DRB reduziria a morbidade $e$ as lesões pulmonares ao abate. Para tanto, objetivou-se avaliar o efeito de dois protocolos metafiláticos sobre a morbidade de bovinos confinados com histórico sanitário conhecido, ocorrência de lesões pulmonares no abate e possível participação de Mannheimia haemolytica, Histophilus somni, Alphaherpesvirus bovino 1 (BoHV-1) e Virus respiratório sincicial bovino (BRSV) na DRB. Foram avaliados 3.094 bovinos adultos, machos, agrupados de acordo com o risco de desenvolvimento de DRB: a) grupo sem metafilaxia ( $n=2.104)$, animais de baixo risco; b) grupo metafilaxia com oxitetraciclina $(n=789)$, animais de risco moderado; c) grupo metafilaxia com tildipirosina ( $n=201)$, animais de alto risco. Todos os animais foram previamente vacinados contra os principais agentes virais causadores das DRB (BoHV-1, BVDV, BRSV e PI3). A morbidade para DRB foi de 8,2\% com menor frequência em animais com risco moderado e metafilaxia com oxitetraciclina (6,1\%), seguido por animais com alto risco com metafilaxia com tildipirosina $(6,5 \%)$ e animais com baixo risco sem metafilaxia $(9,1 \%)(P=0,019)$. No frigorifico, foram encontrados 1,2\% 1,2\% de animais com lesões pulmonares. Houve diferença $(P=0,036)$ na frequência de lesões pulmonares entre animais saudáveis $(1,1 \%)$ e aqueles diagnosticados com DRB $(2,8 \%)$. Foram identificados dois agentes associados à DRB pela técnica de PCR nos pulmões ( $n=37)$ dos bovinos: M. haemolytica $(16,2 \%)$ e H. somni (5,4\%). Adicionalmente, infecções concomitantes envolvendo estes potenciais patógenos foram identificadas nos pulmões de dois animais. Concluiu-se que o uso de protocolos metafiláticos, com base no risco de desenvolvimento de DRB, reduziu a morbidade e a ocorrência de lesões pulmonares nos bovinos acometidos que foram identificadas com maior frequência em animais com histórico de DRB.

Palavras-chave: Histophilus somni, Mannheimia haemolytica, lesões pulmonares.

\section{INTRODUCTION}

The bovine respiratory diseases (BRD) complex is a multifactorial entity, since there is interaction between stress factors and the susceptibility of the host to viral and bacterial agents (DEDONDER \& APLEY, 2015). Consequently, clinically $\mathrm{BRD}$ is due to a complex interaction 
between the host, environmental conditions, and the pathogen (LUBBERS \& TURNIDGE, 2014).

In beef cattle, BRD results in the impairment of the animal health and welfare, as well as a significant economic impact (YOUNG \& WOOLUMS, 2014), since it negatively affects productive indices such as weight gain, loin eye area, marbling, and finishing of the carcass (LARSON, 2005). Several factors that interfere with the incidence, severity, and economic implications of BRD have been thoroughly investigated in the USA and Australia. However, the investigation of the infectious agents and the economic impacts of BRD on feedlot cattle are sparse in Brazil. Notwithstanding this, we have estimated that the loss of revenue due to BRD in Brazil might be at $\$ 14,334.00 / 10,000$ cattle associated with mortality, while BRD-related morbidity was estimated at $\$ 16,315.40 / 10,000$ cattle (BAPTISTA et al., 2017). In addition, our group has identified Histophilus somni (HEADLEY et al., 2014; HEADLEY et al., 2017), Mannheimia haemolytica, Pasteurella multocida (BAPTISTA et al., 2017), and the bovine respiratory syncytial virus, BRSV (HEADLEY et al., 2017) in association with BRD in beef cattle feedlots.

An accurate diagnosis of BRD is of utmost importance to improve disease management and prevention (THEURER et al., 2015). However, cattle with disease may not always demonstrate the clinical signs that are characteristic of BRD (FULTON, 2013). Schneider et al. (2009) have suggested that $60 \%$ of feedlot cattle may have pulmonary lesions related with BRD but are not identified as being affected during the period on feed. Although, an incidence of $8.3 \%$ of pulmonary hepatisation was described in slaughtered cattle from Brazil (VECHIATO, 2009). This alteration was not associated with the clinical history of affected cattle.

The hypothesis of this study was that the utilization of metaphylactic protocols, according to the risk to develop DRB, would reduce morbidity and pulmonary disease of cattle with this disease. Consequently, the objectives of this investigation were to evaluate the effects of two metaphylactic protocols on the morbidity of feedlot cattle with known sanitary history, the occurrence of pulmonary lesions at slaughter, and the participation of $M$. haemolytica, $H$. somni, bovine alphaherpevirus 1 (BoHV-1), and BRSV in the development of BRD in a feedlot from Brazil.

\section{MATERIALS AND METHODS}

During this experiment, 3,094 animals from a commercial beef cattle feedlot, located in the northwestern region of the state of Minas Gerais, Brazil, were monitored between April and August 2015. During this period, the mean minimum and maximum daily temperatures were $15.5 \pm 3.2^{\circ} \mathrm{C}$ and $34.6 \pm 4.5^{\circ} \mathrm{C}$, respectively, with an average rainfall index of $0.98 \pm 5.38 \mathrm{~mm}$. The uncastrated male cattle, had a mean age of 20 months and weight of $324.2 \pm 48.66 \mathrm{~kg}$ on the entering the feedlot and remained on feed for $130.4 \pm 18.59$ days. All cattle were immunized against clostridial diseases (COVEXIN 9 ${ }^{\circledR}$, MSD Saúde Animal, Brazil; LINOVAC ${ }^{\circledR}$, Merial, Brazil) and infectious disease pathogens associated with BRD (Cattlemaster $4^{\circledR}$, Zoetis, Brazil). The experimental groups were maintained in pickets $(n=140)$ of $1,452 \mathrm{~m}^{2}$ and received corn silage, flocculated corn, cottonseed meal, soybean molasses, mineral salts, and water ad libitum. To reduce the effects of dust on the steers within the pickets, water sprinklers were used, twice per day.

All cattle were divided into three experimental groups based on the risk of developing BRD. A) group without metaphylaxis, $(n=2,104)$, cattle with reduced risk, reared on location, no dislocation, known origin, body condition score (BCS) $\geq 3$; or acquired from external source, unknown origin, $\mathrm{BCS} \geq 3$, dislocation $<500 \mathrm{~km}$ during $<8$ hours and three days of rest on arrival at the feedlot; B) metaphylaxis with oxytetracycline, $(n=789)$, cattle with moderate risk, reared on location, and BCS 1 or 2 , or cattle acquired from external source, origin unknown, BCS 1 or 2 , dislocation $<500 \mathrm{~km}$ in $<8$ hours, and three days of rest on arrival at the feedlot; or cattle acquired from external source, $\mathrm{BCS} \geq 3$, dislocation $>500 \mathrm{~km}$ during $>8$ hours, six days rest on arrival at the feedlot and metaphylactic therapy with oxytetracycline (REVERIN $^{\circledR}$ LA PLUS, MSD), administered in a single dose of $20 \mathrm{mg} \cdot \mathrm{kg}^{-1} \mathrm{BW}$, IM; C) metaphylaxis with tildipirosin $(n=201)$, cattle with elevated risk, reared on location with BCS 1 or 2; or acquired from external source, BCS 1 and 2, dislocation $<500 \mathrm{~km}$ during $<8$ hours and three days of rest on arrival at feedlot; or acquired from external source, $\mathrm{BCS} \geq 3$, dislocation $>500 \mathrm{~km}$ during $>8$ hours, with six hours of rest on arrival at the feedlot and metaphylactic therapy with tildipirosin $\left(Z U P R E V O{ }^{\circledR}, M S D\right)$, administered in a single dose of $4 \mathrm{mg} \cdot \mathrm{kg}^{-1} \mathrm{BW}$, SC.

All cattle with clinical symptoms of BRD were medicated with florfenicol (40mg. $\mathrm{kg}^{-1}$ ) and flunixin meglumine (2.2mg. $\mathrm{kg}^{-1}$; RESFLOR ${ }^{\circledR}$ GOLD, MSD). Characterization of respiratory disease was based on the DART system (Zoetis, Florham Park, NJ, USA), modified by (WILSON et al., 2015). All cattle were slaughtered between August to December 
2015. Pulmonary alterations were classified based on the score system adapted by BRYANT et al. (1999).

Nucleic acids (DNA and/or RNA) were extracted from pulmonary fragments $(n=37)$ as described (BOOM et al., 1990), and used in PCR/RTPCR assays designed to identify specific genes of BRD infectious agents. These included the $16 \mathrm{~s}$ rRNA gene of H. somni (ANGEN et al., 1998), the intragenic region lktA-artJ of M. haemolytica (ANGEN et al., 2009), the glycoprotein $\mathrm{C}$ gene of BoHV-1 (TRAESEL et al., 2012), and the glycoprotein G gene of BRSV (VILCEK et al., 1994). Positive controls included DNA/RNA from cell culture adapted Los Angeles strain of BoHV1 (CLAUS et al., 2005), H. somni (HEADLEY et al., 2013), BRSV, M. haemolytica (HEADLEY et al., 2014; HEADLEY et al., 2017) obtained from previous studies. Nuclease-free (Invitrogen Corp., Carlsbad, CA, USA) water was used as negative controls in all PCR/RT-PCR assays.

The products of all assays were separated by electrophoresis in $2 \%$ agarose gels, stained with ethidium bromide, and examined under ultraviolet light. Amplified PCR/RT-PCR products were then purified (GE Healthcare, Little Chalfonte, Buckinghamshire, UK) and submitted for direct sequencing using the forward and reverse primers; sequencing was performed by using a BigDye Terminator v3.1 Cycle Sequencing Kit (Applied Biosystems, Carlsbad, California, USA.) in a 3500 Genetic Analyzer (Applied Biosystems, Foster City, CA, USA) sequencer. Partial nucleotide sequences obtained were compared by the Basic Local Alignment Search Tool (BLAST) program $<$ http://www.ncbi.
nlm.nih.gov/BLAST $>$ with similar sequences deposited in GenBank.

Data relative to the clinical diagnosis of $\mathrm{BRD}$, therapy, morbidity, and productive indices were collected daily and used as input data to a Microsoft Excel spread sheet. The morbidity and pulmonary lesions were presented as percentages and the results compared by the Chi-square test $(\mathrm{P}<0.05)$ with the Minitab software v.16 (Minitab Inc., PA, USA).

\section{RESULTS}

During this study, $8.2 \%(253 / 3,094)$ of the cattle evaluated had clinical manifestations of BRD, with different frequency $(P=0.019)$ between the groups of animals evaluated (Figure 1). The lowest frequency was reported in the cattle with moderate risk for BRD under the metaphylaxis oxytetracycline protocol $(6.1 \%$ - 48/789), followed by cattle with elevated risk for BRD subjected to the tildipirosin metaphylactic procedure $(6.5 \%-13 / 201)$, and those with reduced risk for BRD and without any metaphylactic protocol $(9.1 \%$ - 192/2,104).

Gross evaluation of the lungs of the cattle at the slaughter house revealed that pulmonary lesions indicative of BRD were identified in $1.2 \%(37 / 3,094)$ of the lungs examined. From this number of affected lungs, $18.9 \%$ (7/37) of these were from cattle diagnosed with BRD and treated while on feed, while $81.1 \%$ (30/37) represented cattle that were not diagnosed with BRD and consequently not treated (Figure 1). Furthermore, there was a difference $(P=0.036)$ in the frequency of pulmonary lesions by the DART system, between healthy cattle $(1.1 \%-30 / 2,841)$ and those

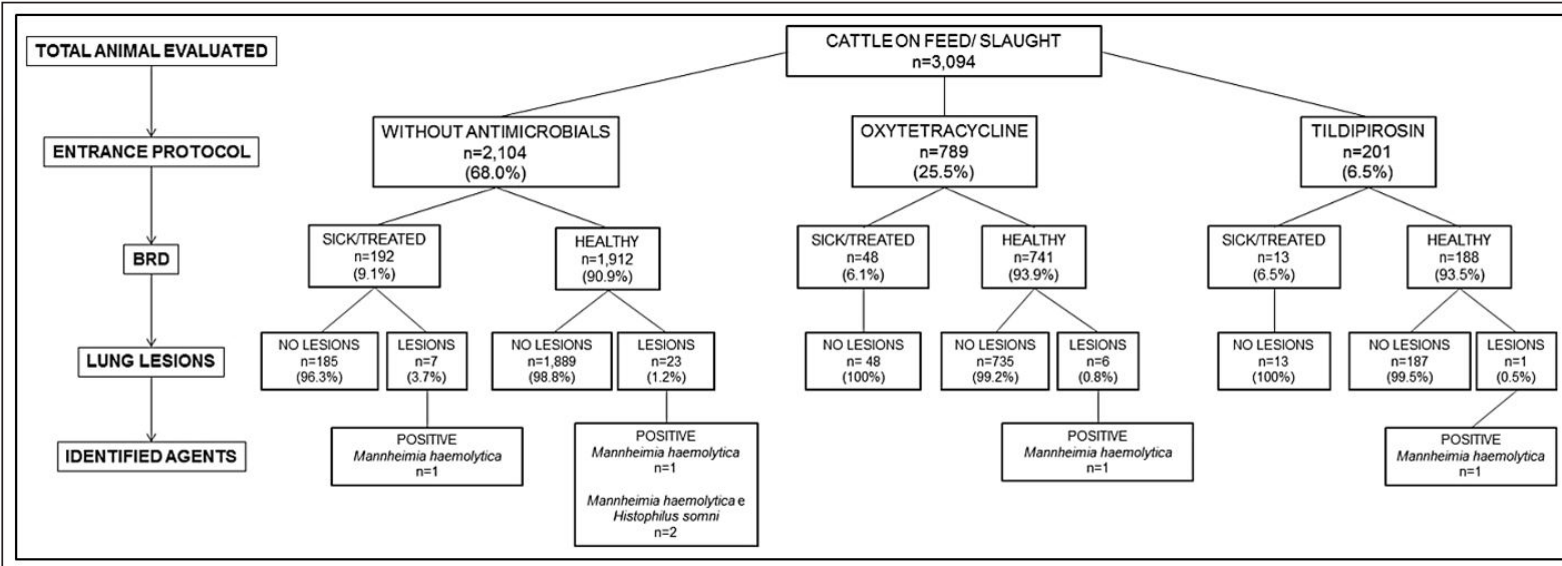

Figure 1 - Fluxogram demonstrating the number of cattle evaluated per metaphylactic protocol. For each metaphylactic group (without antimicrobial; oxytetracycline; and tildipirosin) the number of cattle with or without BRD is given, followed by the number of lesions reported in the lungs during the inspection. Finally, agents identified by the PCR assays are indicated (Positive) with $M$. haemolytica being the agent in all identified lesions. 
diagnosed with BRD (2.8\% - 7/253); these seven steers were from the low-risk group without metaphylaxis. In addition, the relatively reduced percentage $(1.1 \%$ $30 / 2,841$ ) of cattle without BRD but with pulmonary lesions were considered as cattle with subclinical manifestations of BRD.

Molecular investigations revealed that only bacterial agents associated with BRD were identified in the lungs of the cattle evaluated; nucleic acids of BRSV and BoHV-1 were not identified in any pulmonary fragments. $M$. haemolytica DNA was amplified in $16.2 \%(6 / 37)$ of all cattle evaluated (Table 1) but was more predominant in cattle without any metaphylaxis. However, H. somni DNA was only amplified in the lungs of cattle without any metaphylactic protocol against BRD and resulted in 5.4\% (2/37) of all cattle evaluated. Furthermore, there were two cases of coinfections due to $M$. haemolytica and $H$. somni. Direct sequencing confirmed the PCR results; the sequences derived from this study are deposited in GenBank (M. haemolytica MF116218; H. somni-MF094888).

\section{DISCUSSION}

During this study metaphylaxis was efficient in reducing the rates of BRD-related morbidity; and therefore, accomplished the objective of this prophylactic therapy (SWEIGER \& NICHOLS, 2010). Furthermore, metaphylaxis reduced the rates of morbidity mainly in cattle with elevated BRD risk, being within the recommended level of 10\% (APLEY, 2015).

Visual evaluation of clinical signs associated with BRD is a method that standardizes the identification of this disease and does not require expensive equipment or tools (LOVE et al., 2014). Although some authors have considered this method as being of low sensitivity and specificity (AMRINE et al., 2014), during this study the DART system was efficient in identifying diseased cattle, since only $1.1 \%$ of those not treated for BRD had pulmonary lesions. This percentage was approximately seven times lower than that identified in another study from Brazil
(VECHIATO, 2009), where $8.3 \%$ of the lungs had lesions. However, in that study (VECHIATO, 2009), there was no follow-up of cattle prior to slaughter to characterize the profile of the animals with $\mathrm{BRD}$, while in the present study there was the correlation between the animal health history and the pulmonary lesions observed at slaughter. In addition, when all cattle that were medicated for BRD were evaluated, pulmonary lesions were observed only in those that were in the group without metaphylaxis therapy. This then suggests that the DART system in association with metaphylaxis contributed to the insignificant manifestations of BRD and reduced the incidence in $60 \%$ of the pulmonary lesions expected in cattle without clinical manifestations of BRD while on feed (SCHNEIDER et al., 2009).

During this study, M. haemolytica was investigated because of the elevated incidence of this bacterial agent associated with BRD in cattle from North America (AMRINE et al., 2014), while H. somni is an emerging disease pathogen of ruminants in Brazil (HEADLEY et al., 2013). Although the viral agents included in this study are frequently associated with BRD in feedlot cattle from North America, extensive epidemiological studies confirming the participation of these agents in the development of BRD in cattle from Brazil are inexistent. Nevertheless, BRSV was associated with BRD in feedlot cattle from the state of São Paulo, Brazil, where there were coinfections due to BRSV and H. somni (HEADLEY et al., 2017). Furthermore, we have described the concomitant participation of BoHV-1 and $H$. somni in the development of BRD in feedlot cattle from Northern Paraná (HEADLEY et al., 2014). However, during this study only bacterial pathogens were associated with $\mathrm{BRD}$; similar results were identified in feedlot from the state of Minas Gerais (BAPTISTA et al., 2017).

Consequently, BRD-related viral pathogens could have been associated with the initial period of infection at the feedlot, but absent at the time of slaughter and thereby not identified. The incidence of BRD is more predominant during the initial phase of cattle maintained on feed in North America

Table 1 - Distribution of infectious agents identified in each metaphylactic protocol by PCR.

\begin{tabular}{|c|c|c|c|c|}
\hline Infectious agents identified & Without antimicrobial & Oxytetracycline & Tildipirosin & Total \\
\hline M. haemolytica & $13.3 \%(4 / 30)$ & $16.7 \%(1 / 6)$ & $100 \%(1 / 1)$ & $16.2 \%(6 / 37)$ \\
\hline H. somni & $6.7 \%(2 / 30)$ & 0 & 0 & $5.4 \%(2 / 37)$ \\
\hline Bovine alphaherpesvirus-1 & 0 & 0 & 0 & 0 \\
\hline Bovine respiratory syncytial virus & 0 & 0 & 0 & 0 \\
\hline
\end{tabular}


(LARSON, 2015) and Brazil (BAPTISTA et al., 2017); however, in this case sampling for the presence of infectious agents was only done at slaughter. In addition, the absence of viral pathogens during this study can be related to the fact that all cattle were immunized against most viral disease agents of BRD on entering the feedlot. This probably minimized the effects of possible viral disease pathogens due to the greater degree of circulating antibodies, resulting in better performance and reduced intensity of clinical disease (FULTON, 2013).

\section{CONCLUSION}

The utilization of the metaphylactic protocols based on the risk to develop bovine respiratory disease was efficient in reducing the morbidity and the number of lungs with pulmonary disease. Pulmonary lesions were predominant in cattle with $\mathrm{BRD}$, and $H$. somni and M. haemolytica were associated with pulmonary diseases.

\section{BIOETHICS AND BIOSSECURITY COMMITTEE APPROVAL}

We authors of the study entitled "The effects of the use of metaphylactic protocols based on the risk to develop bovine respiratory diseases in feedlot cattle" declared, for all due purposes, the project that gave rise to the present data has not been submitted for evaluation to the Ethics Committee of the Universidade Federal de Uberlândia, but we are aware of the content of the Brazilian resolutions of the Conselho Nacional de Controle de Experimentação Animal (CONCEA) <http://www.mct.gov.br/index.php/content/ view/310553.html $>$ if it involves animals.

Thus, the authors assume full responsibility for the presented data and are available for possible questions, should they be required by the competent authorities.

\section{ACKNOWLEDGEMENTS}

The authors thank Conselho Nacional de Desenvolvimento Científico e Tecnológico (CNPq), Fundação de Amparo à Pesquisa do Estado de Minas Gerais (FAPEMIG), and Coordenação de Aperfeiçoamento de Pessoal de Nível Superior (CAPES) for financial support.

\section{REFERENCES}

AMRINE, D.E. et al. Pulmonary lesions and clinical disease response to Mannheimia haemolytica challenge 10 days following administration of tildipirosin or tulathromycin. Journal of Animal Science, v.92, p.311-319, 2014. Available from: $<$ https:// dl.sciencesocieties.org/publications/jas/abstracts/92/1/311>. Accessed: July 20, 2016. doi:10.2527/jas.2013-6577.

ANGEN, Ø. et al. Development of a PCR test for identification of Haemophilus somnus in pure and mixed cultures. Veterinary Microbiology, v.63, n.1, p.39-48, 1998. Available from: <http://
dx.doi.org/10.1016/S0378-1135(98)00222-3>. Accessed: May 08, 2016. doi: 10.1016/S0378-1135(98)00222-3.

ANGEN, Ø. et al. Respiratory disease in calves: Microbiological investigations on trans-tracheally aspirated bronchoalveolar fluid and acute phase protein response. Veterinary Microbiology, v.137, n.1-2, p.165-171, 2009. Available from: <http://dx.doi. org/10.1016/j.vetmic.2008.12.024>. Accessed: May 08, 2016. doi: 10.1016/j.vetmic.2008.12.024.

APLEY, M.D. Feedlot pharmaceutical documentation: protocols, prescriptions, and veterinary feed directives. Veterinary Clinics of North America: Food Animal Practice, v.31, n.2, p.305-315, 2015. Available from: <http://dx.doi.org/10.1016/j. cvfa.2015.03.004>. Accessed: Dec. 10, 2015. doi: 10.1016/j. cvfa.2015.03.004.

BAPTISTA, A.L. et al. Bovine respiratory disease complex associated mortality and morbidity rates in feedlot cattle from Southeastern Brazil. The Journal of Infection in Developing Countries, Accept for publication, 2017.

BOOM, R. et al. Rapid and simple method for purification of nucleic acids. Journal of Clinical Microbiology, v.28, n.3, p.495503, 1990. Available from: <http://jcm.asm.org/>. Accessed: May 05, 2016. doi: 0095-1137/90/030495-09\$02.00/0.

BRYANT, L.K. et al. A method for recording pulmonary lesions of beef calves at slaughter, and the association of lesions with average daily gain. Bovine Practice, v.33, p.163-173, 1999. Available from: $<$ http://cat.inist.fr/?aModele=afficheN\&cpsidt=10143202>. Accessed: Mar. 02, 2016. doi: 10.2527/jas.2008-1283.

CLAUS, M.P. et al. Rapid detection and differentiation of bovine herpesvirus 1 and 5 glycoprotein $\mathrm{C}$ gene in clinical specimens by multiplex-PCR. Journal of Virological Methods, v.128, n.1-2, p.183-138, 2005. Available from: <http://www.ncbi.nlm.nih.gov/ pubmed/15939490>. Accessed: Mar. 19, 2017 doi: 10.1016/j. jviromet.2005.05.001

DEDONDER, K.D.; APLEY, M.D. A literature review of antimicrobial resistance in Pathogens associated with bovine respiratory disease. Animal Health Research Reviews, v.16, n.02, p.125-134, 2015. Available from: <http://dx.doi.org/10.1017/ S146625231500016X>. Accessed: July 20, 2016. doi: 10.1017/ S146625231500016X.

FULTON, R.W. Host response to bovine viral diarrhea virus and interactions with infectious agents in the feedlot and breeding herd. Biologicals, v.41, n.1, p.31-38, 2013. Available from: <http:// dx.doi.org/10.1016/j.biologicals.2012.07.009>. Accessed: Aug. 25, 2016. doi: 10.1016/j.biologicals.2012.07.009.

HEADLEY, S. et al. Bovine respiratory disease associated with Histophilus somni and bovine respiratory syncytial virus in a beef cattle feedlot from Southeastern Brazil. Semina: Ciências Agrárias, v.38, n.1, p.283-294, 2017. Available from: <http://www.uel.br/revistas/uel/index.php/semagrarias/ article/view/25499/20670>. Accessed: Mar. 02, 2017. doi: $10.5433 / 1679-0359.2017 \mathrm{v} 38 \mathrm{n} 1 \mathrm{p} 283$.

HEADLEY, S.A. et al. Histophilus somni is a potential threat to beef cattle feedlots in Brazil. Veterinary Record, v.175, n.10, p.249, 2014. Available from: <http://veterinaryrecord.bmj.com/ content/early/2014/07/10/vr.102562.short>. Accessed: Feb. 20, 2015. doi: $10.1136 /$ vr. 102562 . 
HEADLEY, S.A. et al. Histophilus somni-induced infections in cattle from southern Brazil. Tropical Animal Health and Production, v.45, n.7, p.1579-1588, 2013. Available from: <http:// dx.doi.org/10.1007/s11250-013-0402-7>. Accessed: Aug. 25, 2016. doi: 10.1007/s11250-013-0402-7.

LARSON, R.L. Effect of cattle disease on carcass traits. Journal of Animal Science, v.83, supl, p.37-43, 2005. Available from: $<$ https://dl.sciencesocieties.org/publications/jas/abstracts /83/13_suppl/0830037>. Accessed: Aug. 12, 2016. doi: $10.2527 / 2005.8313$ _supplE37x.

LARSON, R.L. Bovine viral diarrhea virus-associated disease in feedlot cattle. Veterinary Clinics of North America: Food Animal Practice, v.31, n.3, p.367, 2015. Available from: <http:// dx.doi.org/10.1016/j.cvfa.2015.05.007>. Accessed: Dec. 10, 2015. doi: $10.1016 /$ j.cvfa.2015.05.007.

LOVE, W.J. et al. Development of a novel clinical scoring system for on-farm diagnosis of bovine respiratory disease in pre-weaned dairy calves. PeerJ, v.2, p,1-25, 2014. Available from: <http:// dx.doi.org/10.7717/peerj.238>. Accessed: July 20, 2016. doi: 10.7717/peerj.238.

LUBBERS, B.V.; TURNIDGE, J. Antimicrobial susceptibility testing for bovine respiratory disease: getting more from diagnostic results. Veterinary Journal, v.203, n.2, p.149-154, 2014. Available from: <http://dx.doi.org/10.1016/j.tvj1.2014.12.009>. Accessed: July 20, 2016. doi: 10.1016/j.tvj1.2014.12.009.

SCHNEIDER, M.J. et al. An evaluation of bovine respiratory disease complex in feedlot cattle: impact on performance and carcass traits using treatment records and lung lesion scores. Journal of Animal Science, v.87, n.5, p.1821-1827, 2009. Available from: <https:// www.ncbi.nlm.nih.gov/pubmed/19181770>. Accessed: Aug. 11, 2016. doi: $10.2527 /$ jas.2008-1283.

SWEIGER, S.H.; NICHOLS, M.D. Control methods for bovine respiratory disease in stocker cattle. Veterinary Clinics of North America Food Animal Practice, v.26, n.2, p.261271, 2010. Available from: < https://www.ncbi.nlm.nih.gov/ pubmed/20619183>. Accessed: Dec. 10, 2015. doi: 10.1016/j. cvfa.2010.04.008.

THEURER, M.E. et al. A stochastic model to determine the economic value of changing diagnostic test characteristics for identification of cattle for treatment of bovine respiratory disease. Journal of Animal Science, v.93, p.1398-1410, 2015. Available from: <https://www.ncbi.nlm.nih.gov/pubmed/26020916>. Accessed: July 20, 2016. doi: 10.2527/jas2014-8487.

TRAESEL, C. et al. Nucleotide sequencing and phylogenetic analysis of the 3' region of glycoprotein $\mathrm{C}$ gene of South American bovine herpesviruses 1 and 5. Research in Veterinary Science, v.94, n.1, p.178-185, 2012. Available from: <http://dx.doi. org/10.1016/j.rvsc.2012.07.032>. Accessed: May 08, 2016. doi: 10.1016/j.rvsc.2012.07.032.

VECHIATO, T.A.F. Estudo retrospectivo e prospectivo da presença de abscessos hepaticos em bovinos abatidos em um frigorífico paulista. 2009. 102f. - Clínica Veterinária, Faculdade de Medicina Veterinária e Zootecnia, Universidade de São Paulo, SP.

VILCEK, S. et al. Development of nested PCR assays for detection of Bovine Respiratory Sincytial Virus in clinical samples. Journal of Clinical Microbiology, v.32, n.9, p.2225-2231, 1994. Available from: <http://jcm.asm.org/content/32/9/2225.full.pdf + html $>$. Accessed: May 08, 2016.

WILSON, B.K. et al. Evaluation of multiple ancillary therapies used in combination with an antimicrobial in newly received high-risk calves treated for bovine respiratory disease. Journal of Animal Science, v.93, n.7, p.3661-3674, 2015. Available from: $<$ http://dx.doi.org/10.2527/jas.2015-9023>. Accessed: Apr. 10, 2016. doi: $10.2527 /$ jas.2015-9023.

YOUNG, A.E.; WOOLUMS, A.R. Proceedings of the Bovine Respiratory Disease Symposium 2014: New Approaches to Bovine Respiratory Disease Prevention, Management, and Diagnosis. Animal Health Research Reviews, v.15, n.02, p.119, 2014. Available from: <http://dx.doi.org/10.1017/S1466252314000322>. Accessed: July 20, 2016. doi: 10.1017/S1466252314000322. 